原著

\title{
Single Afferent Nerve Fibers in the Spinal Dorsal Roots Activated by Manual Acupuncture Needle Stimulation in Frog's Hind Limbs
}

\author{
IKEDA Hiroko ${ }^{1}$ UCHIDA Sae ${ }^{2}$ SHIMURA Mayura ${ }^{1}$ \\ SUZUKI Atsuko ${ }^{2}$ AIKAWA Yoshihiro ${ }^{1}$ \\ 1 Graduate School of Humanities and Sciences, \\ Ochanomizu University, 2-1-1, Otsuka, Bunkyo-ku, Tokyo 112-8610 \\ 2 Department of the Autonomic Nervous System, \\ Tokyo Metropolitan Institute of Gerontology, 35-2, Sakaecho, Itabashi-ku, Tokyo 173-0015, Japan
}

\begin{abstract}
The present experiment aimed to determine what kinds of afferent nerve fibers in dorsal roots are stimulated during manual stimulation with an acupuncture needle by using single nerve unit recording techniques in bullfrogs. An acupuncture needle was inserted into a hind limb via the skin to the muscles, and was manually twisted right and left at a frequency of about $1 \mathrm{~Hz}$. Dorsal roots of the 8 th and 9 th spinal nerves were cut close to their entrance into the spinal cord and dissected to record single unitary afferent activity. The conduction velocity of the single nerve fiber was measured. A total of 30 units were successfully dissected, and all of those responded to manual twisting stimulation of the acupuncture needle in a hind limb. All of the dissected fibers had their receptive fields only at the unilateral side ipsilateral, to the recording site never contralateral. The conduction velocities of all 30 units ranged between $5.3-40.7 \mathrm{~m} / \mathrm{s}$. The reports by Erlanger et al. ${ }^{1,2)}$ which showed the maximum conduction velocities of $A \alpha$, $\beta, \delta$ and $C$ afferent fibers in bullfrogs to be about $48.2 \mathrm{~m} / \mathrm{s}, 28.7 \mathrm{~m} / \mathrm{s}, 13.6 \mathrm{~m} / \mathrm{s}$ and $0.7 \mathrm{~m} / \mathrm{s}$, respectively, indicated that all 30 units dissected at the dorsal roots and responding to manual acupuncture stimulation were $A \alpha, \beta, \delta$ fibers. We could not record single nerve unitary activity of $C$ fibers, probably because of technical difficulties. We conclude that manual acupuncture needle stimulation to the hind limbs excites single unitary afferent fibers of $A \alpha$, $\beta$, and $\delta$ fibers in the dorsal roots of bullfrogs.
\end{abstract}

Key words: acupuncture, spinal dorsal roots, single afferent nerve fiber, conduction velocities, frogs

\section{Introduction}

Acupuncture has clinically been used for some kinds of analgesia and also for the adjustment of visceral functions ${ }^{3,4)}$. The main parts of these clinical effects of acupuncture have been shown to be due to primary activation of afferent nerve fibers innervating the skin and muscles by acupuncture needle stimulation ${ }^{4,5)}$. Somatic afferent nerve fibers are composed of $A \alpha, \beta$, $\delta$ and $C$ fibers. It has been discussed which kinds of afferent nerve fibers are stimulated by acupuncture needle stimulation ${ }^{4,6,7)}$. For example, there are some reports that $A \delta^{8)}$ and $\mathrm{C}^{9}$ ) afferent fibers were

干112-0012 東京都文京区大塚2-1-1 お茶の水女子大学 TEL.03-5978-5728 
stimulated by acupuncture in cats, and also that $A \beta$, $A \delta$ and $C$ fibers were stimulated by acupuncture in humans ${ }^{10)}$ through the use of single afferent nerve unit recording techniques. The present experiment aimed to establish which kinds of afferent nerve fibers are stimulated during manual stimulation by an acupuncture needle using single nerve unit recording techniques in bullfrogs. For this purpose we inserted an acupuncture needle in the hind limbs and twisted it manually, and recorded single unitary action potentials from a dissected nerve branch from the $8^{\text {th }}-9^{\text {th }}$ spinal dorsal roots which contain afferent nerve fibers from the hind limb. The conduction velocity of each nerve fiber was measured.

\section{Materials and Methods}

\section{Materials}

The experiments were performed on 18 bullfrogs (Rana catesbeiana). Each animal was decapitated, and the spinal cord was pithed from the decapitated area for a length of about $2 \mathrm{~cm}$ reaching the $4-5^{\text {th }}$ spinal nerve level. The forelimbs and all visceral organs were removed. The vertebra above the $4^{\text {th }}$ spinal nerve level was cut and removed. The final preparation comprised the hind limbs and spinal cord below the $6^{\text {th }}$ spinal nerve level. The edge bone of the vertebra at the $5^{\text {th }}$ spinal nerve level was fixed by a clamp on the experimental stage to prevent movement.

\section{Acupuncture needle stimulation}

An acupuncture needle with a diameter of $340 \mu \mathrm{m}$ (Seirin, Shizuoka) was inserted into a hind limb via the skin and reaching the underlying muscles. The inserted acupuncture needle was manually twisted right and left at a frequency of about $1 \mathrm{~Hz}$ for about 10 seconds

\section{Recordings of single unitary afferent nerve activities}

Dorsal roots of the $8^{\text {th }}$ and $9^{\text {th }}$ spinal nerves were cut close to their entrance into the spinal cord. The central segments of the cut nerves were placed on bipolar platinum-iridium wire recording electrodes. The nerves were kept in a liquid paraffin pool, temperature of which was maintained at about $25^{\circ} \mathrm{C}$ according to the previous method of Erlanger et al. ${ }^{1)}$ Dissection of the dorsal roots was performed using two forceps

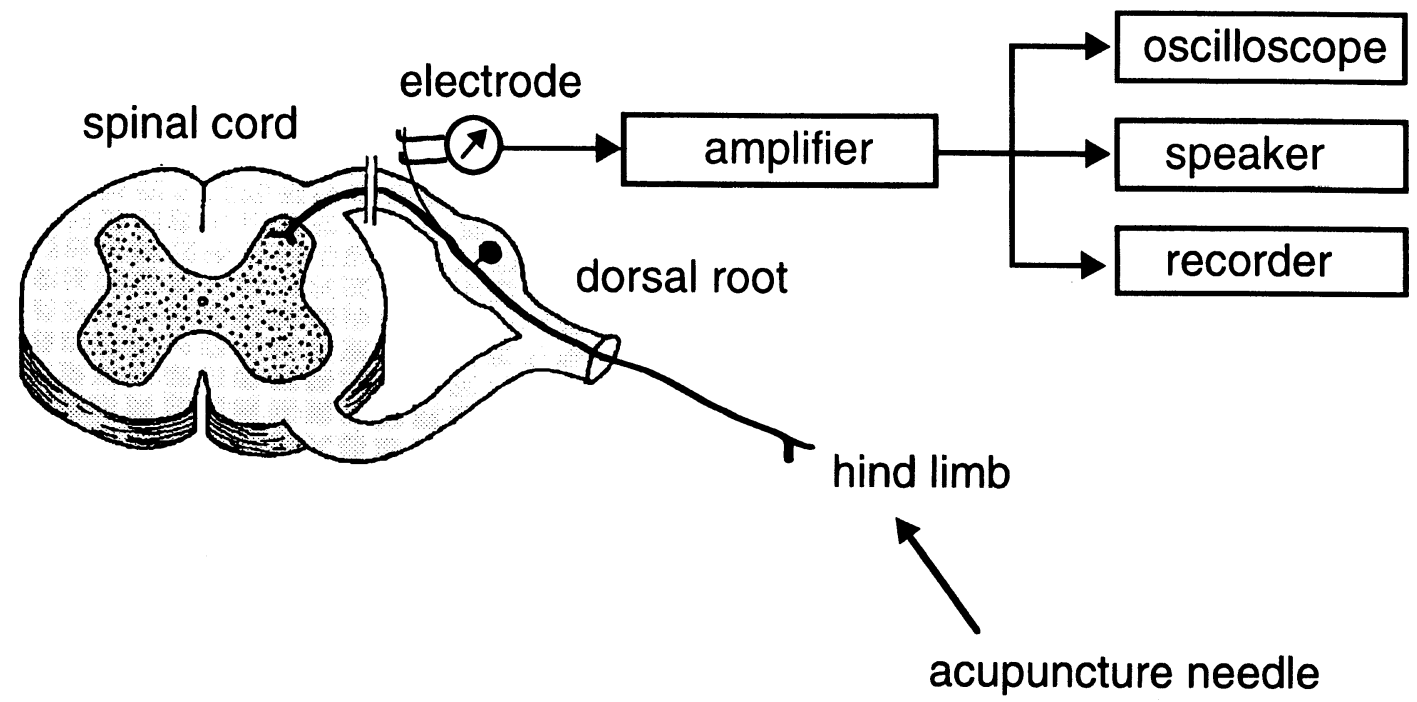

Fig. 1 Schematic drawing of experimental method. 
under a binocular microscope at $20-40 \mathrm{x}$ magnification until we recorded single unitary activity. After the experiment, the nerve length between the proximal acupuncture needle and the distal recording electrode was measured. Single unitary action potentials were amplified by the amplifier (S-0476, Nihon Kohden, Tokyo), connected to a speaker (MEU4SF, Sanyo, Osaka), and were displayed on both a storage oscilloscope (5103Nm, Tektronix, U.S.A.) and a thermal array recorder (WS-682G, Nihon Kohden, Tokyo) (Fig. 1). During the experiments, room temperature was maintained at $25 \pm 1{ }^{\circ} \mathrm{C}$ and humidity of the room was maintained at about $50 \%$.

\section{Measurement of the conduction velocity of a nerve fiber}

When manual stimulation of an acupuncture needle evoked single unitary action potentials in dissected dorsal root nerve fibers, the other acupuncture needle was also inserted about $5 \mathrm{~mm}$ distal to the original needle. A single electric current was passed between these two needles with a square wave pulse (duration $0.5 \mathrm{~ms}$ ) using a constant current electrical stimulator (SEN-7203, Nihon Kohden, Tokyo) with various stimulus intensities. When single electrical stimulation of these two needles in a hind limb evoked unitary action potentials in the dissected dorsal root nerve fibers, the shapes of the action potentials evoked either electrically or manually were identified and compared to determine whether or not they came from a single unit. The conduction velocity of a single nerve fiber was calculated by measuring both the length of the nerve between the proximal acupuncture needle and the distal electrode of bipolar wire recording electrodes and the latency of the evoked action potential in a dissected nerve fiber. The intensities of stimulation were varied between 0.02 $\mathrm{mA}$ and $4.0 \mathrm{~mA}$ to when exciting the afferent fiber.

\section{Results}

Figure 2 shows two example records of single unitary activities. One had a faster conduction velocity and the other had a slower conduction velocity. The unit in Fig. 2A had its receptive field for manual acupuncture needle stimulation in the second and third extensor digitorum longus muscle at the base of a web via the covering skin. Manual twisting movements of acupuncture needle every $1 \mathrm{~Hz}$ to right and left excited this fiber intermittently and synchronously to the manual movements of the needle as shown in Fig. 2Ac. Electrical stimulation of this nerve via two acupuncture needles, one of the two
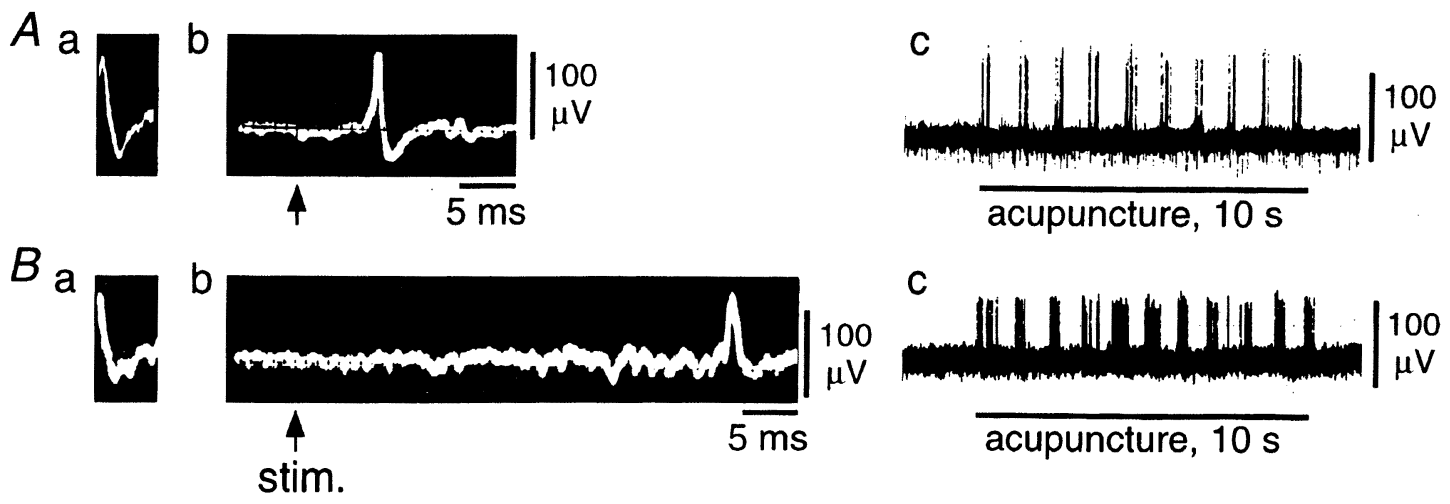

Fig. 2 Example records of single unitary activities induced by acupuncture needle stimulation.

$\mathrm{A}, \mathrm{B}$ indicate the single nerve fiber activities. $\mathrm{Aa}, \mathrm{Ba}$ : Action potentials elicited by manual acupuncture needle stimulation. Ab, Bb: Evoked potential elicited by electrical stimulation of the receptive field via acupuncture two needles. Arrows indicate the onset of stimulation. Ac, Bc: Action potentials recorded for several seconds. The bottom bar indicates manual acupuncture stimulation. 
being in the receptive area, elicited an evoked action potential as shown in Fig. 2Ab. The shape of this evoked action potential (Fig. 2Ab) was exactly identical with that of action potentials elicited by manual acupuncture needle stimulation (Fig. 2Aa). Thus both action potentials elicited manually and electrically were from the same unit. The latency of the electrically evoked action potential (Fig. 2Ab) was $6.0 \mathrm{~ms}$, the distance between the recording electrode and the stimulus needle was $20.5 \mathrm{~cm}$, and the conduction velocity of this unit was thus calculated as $34.2 \mathrm{~m} / \mathrm{s}$.

The unit shown in Fig. 2B had its receptive field in the third, fourth and fifth flexsor digitorum muscle via the covering skin by manual acupuncture needle stimulation. This unit was excited intermittently and synchronously with the $1 \mathrm{~Hz}$ manual twisting movements of a needle (Fig. 2Bc). This unit had an evoked action potential after electrical stimulation via acupuncture needles in the receptive field (Fig. 2Bb). The shapes of electrically evoked action potential (in $\mathrm{Bb}$ ) and manually evoked action potentials (in $\mathrm{Ba}$ ) were identical. The latency of the evoked action potential was $40 \mathrm{~ms}$, and the distance between the recording electrode and the stimulating needles was 21 $\mathrm{cm}$, and its conduction velocity was thus $5.3 \mathrm{~m} / \mathrm{s}$.

In the present experiment, a total of 30 units were successfully dissected, and all of those responded to manual twisting stimulation of an acupuncture needle in a hind limb. All of them had their receptive fields only at the unilateral side ipsilateral to the recording site, never contralateral. The size and shape of the receptive field was variable, maximally extended to 15 mm longitudinally along the leg with a width of 3-5 $\mathrm{mm}$. Figure 3 summarizes all the data of 30 units dissected in a histogram of numbers of 30 units (abscissa) in relation to their conduction velocities (ordinate). The conduction velocities of all 30 units ranged between $5.3 \mathrm{~m} / \mathrm{s}$ and $40.7 \mathrm{~m} / \mathrm{s}$. The histogram had approximately two peaks; the first at $25-35 \mathrm{~m} / \mathrm{s}$ and the second at $5-10 \mathrm{~m} / \mathrm{s}$. The first peak was accompanied by other groups at $15-25 \mathrm{~m} / \mathrm{s}$ and at $35-$ $45 \mathrm{~m} / \mathrm{s}$.

\section{N. Discussion}

The peripheral nerve fibers in frogs have various

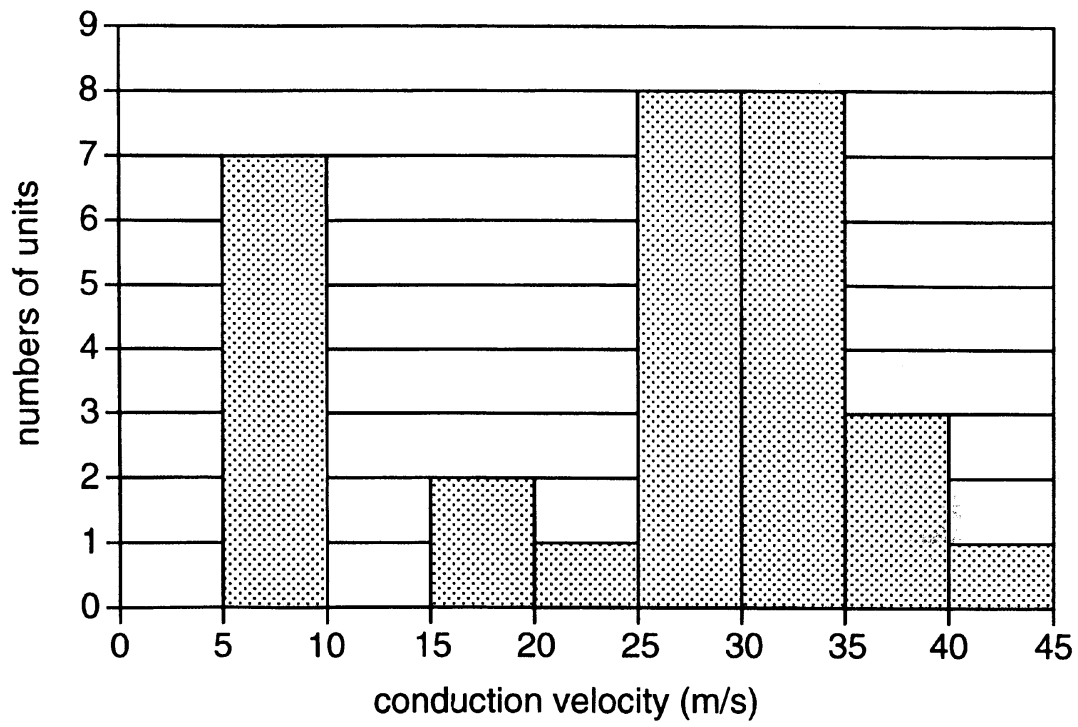

Fig. 3 Histogram of numbers of single nerve units in relation to their conduction velocities. Abscissa: conduction velocity $(\mathrm{m} / \mathrm{s})$. Ordinate: numbers of single nerve units. 
fiber groups such as $\mathrm{A}, \mathrm{B}$ and $\mathrm{C}$ fibers depending on their conduction velocities as reported by Erlanger et al. ${ }^{1,2)}$ As the $\mathrm{B}$ fibers belong to the preganglionic autonomic nerve fibers, they are not contained in limb afferent nerves. The A fibers can be subdivided into $A \alpha, \beta, \gamma, \delta^{1,2)}$. The $A \gamma$ fibers belongs to the efferents and do not exist in dorsal roots. The maximum conduction velocities of $A \alpha, \beta$, and $\delta$ fibers in the bullfrog sciatic nerve were reported as being $48.2 \mathrm{~m} / \mathrm{s}$, $28.7 \mathrm{~m} / \mathrm{s}$ and $13.6 \mathrm{~m} / \mathrm{s}$, respectively (see Table 1 in the original paper by Erlanger et al. ${ }^{1)}$ ). The maximum conduction velocity of $C$ fibers was calculated to be $0.7 \mathrm{~m} / \mathrm{s}$ from figure $4 \mathrm{f}$ of the monograph by Erlanger and Gasser ${ }^{2)}$.

All 30 units in the present study dissected at the dorsal roots and responding to manual acupuncture stimulation should be afferent fibers, not efferent fibers, because they were recorded from dorsal roots. The rationale for dissecting a single fiber in the dorsal root but not in a more peripheral nerve that contained efferent and afferent fibers was to eliminate recording of antidromic activity from efferent nerve fibers. They had conduction velocities between 5.3 and $40.7 \mathrm{~m} / \mathrm{s}$, indicating that all units were $A \alpha, \beta, \delta$ fibers, but not $C$ fibers. As $C$ afferent fibers have been reported to be excited during acupuncture stimulation in cats ${ }^{9}$ or in humans ${ }^{10)}$, we cannot deny the possibility of afferent $C$ fiber excitation during acupuncture stimulation at this time. In fact, our preliminary experiments showed the existence of $\mathrm{C}$ afferent volleys having their conduction velocities of about $0.5 \mathrm{~m} / \mathrm{s}$ recorded from a whole dorsal root following electrical stimulation to acupuncture needles in bullfrog hind limbs. Dissection of single units at the dorsal roots is more difficult technically than such dissection at more peripheral sites.

The present single afferent fibers responding to manual acupuncture needle stimulation could be divided into two main groups. The first group's conduction velocity ranged between 15 and $45 \mathrm{~m} / \mathrm{s}$. These 23 units belonged to the $A \alpha$ and $\beta$ fiber groups. They appear to originate from either muscle spindles, tendon organs, or cutaneous and muscle low threshold mechanoreceptors. As excitation of the low threshold mechanoreceptors has been shown to contribute to analgesia by a gate control theory-like mechanism ${ }^{11}$, 12), the excitation of these $A \alpha$ and $\beta$ afferent fibers during manual acupuncture needle stimulation appears to play an important role in producing analgesia. Excitation of $A \beta$ afferent nerve fibers has been reported to produce acupuncture analgesia in rats ${ }^{13)}$, mice ${ }^{14)}$, rabbits and cats $^{15)}$. Further, it was demonstrated that stimulation of cutaneous low threshold mechanoreceptor afferents inhibited efferent activity of adrenal sympathetic nerves and decreased catecholamine secretion from the adrenal glands in rats $^{16)}$. Therefore the $A \alpha$ and $\beta$ afferent fibers stimulated by manual acupuncture needle may help in inhibiting adrenal sympathetic nerve activity and decreasing secretion of catecholamines from the adrenal glands.

The second group of the present units comprised 7 units, and their latencies were $5-10 \mathrm{~m} / \mathrm{s}$, indicating that they belonged to the A $\delta$ fibers. Paintal ${ }^{8)}$ observed excitation of an A $\delta$ unitary nerve fiber in the cat gastrocnemius-soleus nerve during insertion of a syringe needle into the gastrocnemius-soleus muscles. Excitation of an A $\delta$ unitary fiber in a human median nerve was also induced by acupuncture needle stimulation ${ }^{10)}$. Chung et al. ${ }^{17)}$ recorded a $C$ fiber evoked spinothalamic neural response to stimulation of a hind limb cutaneous sural nerve, and the response was inhibited effectively by stimulation of $A \delta$ afferents in a hind limb muscle tibial nerve in monkeys. They suggested a main contribution of $A \delta$ afferent excitation to segmetal analgesia by peripheral nerve stimulation. Kawakita and Funakoshi ${ }^{18)}$ found that a jaw opening reflex elicited by stimulation of the tooth pulp was inhibited by stimulation of A $\delta$ afferent fibers in a common peroneal nerve in rats, and suggested a contribution of $A \delta$ afferents to acupuncture-induced analgesia. Uchida et al. ${ }^{19)}$ emphasized the importance of $\mathrm{A} \delta$ and $\mathrm{C}$ afferent fiber excitation during acupuncture stimulation to produce a 
vasodilatory response in cerebral cortical blood vessels in rats. Ohsawa et al. ${ }^{20)}$ emphasized the importance of excitation of $A \beta, \delta$ and $C$ afferent fibers during acupuncture stimulation to produce a pupillary dilation reflex response in rats. The present finding of excitation of $\mathrm{A} \delta$ afferent fibers during manual acupuncture needle stimulation in the bullfrog accords with those results mentioned above in rats.

\section{Conclusion}

It is concluded that manual acupuncture needle stimulation to the hind limbs excites single unitary afferent fibers in the dorsal root that belong to $A \alpha, \beta$ and $\delta$ fibers in bullfrogs. However, we may need further study to find afferent $\mathrm{C}$ fibers exciting in response to acupuncture stimulation.

\section{Acknowledgements}

We are grateful to Dr. Akio Sato, Professor of Graduate School of Humanities and Sciences, Ochanomizu University, and also Professor of University of Human Arts and Sciences for his encouragement in finishing this study.

\section{References}

1) Erlanger J, Gasser HS, Bishop GH. The compound nature of the action current of nerve as disclosed by the cathode ray oscillograph. Am J Physiol. 1924;70:624-66.

2 ) Erlanger J, Gasser HS, Electrical Signs of Nervous Activity. Philadelphia. University of Pennsylvania Press. 1937.

3 ) Mann F. Textbook of Acupuncture. London. William Heinemann Medical Books. 1987.

4 ) Stux G, Pomeranz B. Basics of Acupuncture. 4th ed. Berlin. Springer-Verlag. 1998.

5 ) Sato A, Sato Y, Suzuki A, Uchida S. Reflex modulation of gastric and vesical function by acupuncture-like stimulation in anesthetized rats. Biomed Res. 1994;15:59-65.

6 ) Weidmann S. Work in progress at the Shanghai Institute of Physiology, Division of Acupuncture.
Experientia. 1978;34:964-9.

7 ) Chan SHH. What is being stimulated in acupuncture: Evaluation of the existence of a specific substrate. Neurosci Biobehav Rev. 1984;8:25-33.

8 ) Paintal AS. Functional Analysis of group III afferent fibres of mammalian muscles. J Physiol. 1960;152:250-70.

9 ) Wei J-Y, Chang S-C, Feng C-C. Activation of unmyelinated muscle afferents by acupuncture and pressure exerted on muscle. Kexue Tongbao. 1976;21:505-6 (in Chinese).

10) Wang KM, Yao SM, Xian YL, Hou ZL. A study on the receptive field of acupoints and the relationship between characteristics of needling sensation and groups of afferent fibres. Sci Sin B. 1985;28:963-71.

11) Melzack R, Wall PD. Pain mechanisms: A new theory. Science. 1965;150:971-9.

12) Melzack R, Wall PD. The Challenge of Pain. Middlesex. Penguin Books. 1982.

13) Toda K. Effects of electro-acupuncture on rat jaw opening reflex elicited by tooth pulp stimulation. Jpn J Physiol. 1978;28:485-97.

14) Pomeranz B, Paley D. Electroacupuncture hyalgesia is mediated by afferent nerve impulses: An electrophysiological study in mice. Exp Neurol. 1979;66:398-402.

15) Lu G-W. Characteristics of afferent fiber innervation on acupuncture points zusanli. Am J Physiol. 1983;245:R606-12.

16) Araki $T$, Ito $K$, Kurosawa M, Sato A. Responses of adrenal sympathetic nerve activity and catecholamine secretion to cutaneous stimulation in anesthetized rats. Neuroscience. 1984;12:28999.

17) Chung JM, Lee KH, Hori Y, Endo K, Willis WD. Factors influencing peripheral nerve stimulation produced inhibition of primate spinothalamic tract cells. Pain. 1984;19:277-93.

18) Kawakita K, Funakoshi M. Suppression of the jaw-opening reflex by conditioning A-delta fiber stimulation and electroacupuncture in the rat. Exp 
Neurol. 1982;78:461-5.

19) Uchida S, Kagitani F, Suzuki A, Aikawa Y. Effect of acupuncture-like stimulation on cortical cerebral blood flow in anethetized rats. Jpn J Physiol. 2000;50:495-507.
20) Ohsawa $H$, Yamaguchi $S$, Ishimaru $H$, Shimura M, Sato Y. Neural mechanism of pupillary dilation elicited by electro-acupuncture stimulation in anesthetized rats. J Auton Nerv Syst. 1997;64:101-6.

\section{要 旨}

本研究は鍼刺激によりどの種類の体性求心性神経線維が興奮するかを、ウシガエル脊䯣後根の単一求心 性神経線維の活動電位を記録することで特定した。毫銊をカエル後肢の皮膚から筋へ刺入し、約 $1 \mathrm{~Hz} の$ 頻度で左右に回転させた。第 $8-9$ 春髄後根を切断、分離し、単一求心性神経線維の活動電位を記録し た。神経の最大伝導速度も記録した。記録に成功した30本の単一神経線維全てが後肢鍼刺激に応じた。最 大伝導速度は5.3〜 40.7 m/sの範囲内にあった。Erlangerらによるカエル末梢神経のA $\alpha, \beta, \delta, C$ 線維の最大伝導 速度を調べた報告から、本研究で銊刺激に応じた神経線維はA $\alpha, \beta, \delta$ 線維に相当する。本研究では技術上の 問題から単一C線維の活動を記録できなかったが、C線維が鍼で興奮する可能性は否定できない。以上か らカエル後肢への鍼刺激は脊髄後根のA $\alpha, \beta, \delta$ 求心性線維を興奮させることが明らかになった。

キーワード : 銊、脊䯣後根、単一求心性神経線維、伝導速度、カエル 